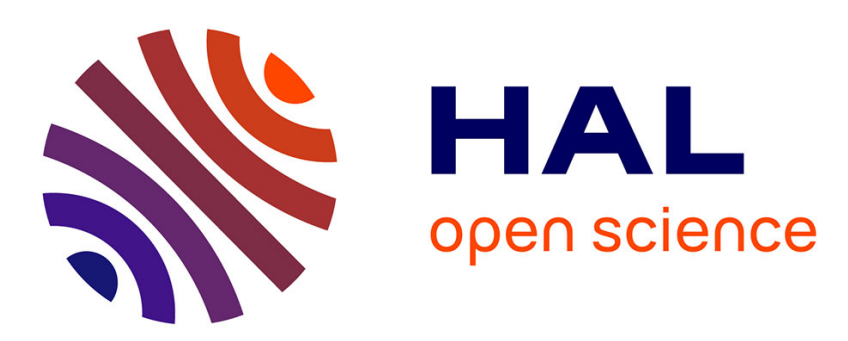

\title{
An enzymatic biofuel cell based on electrically wired polyphenol oxidase and glucose oxidase operating under physiological conditions
}

Fabien Giroud, Chantal Gondran, Karine Gorgy, Vincent Vivier, Serge Cosnier

\section{- To cite this version:}

Fabien Giroud, Chantal Gondran, Karine Gorgy, Vincent Vivier, Serge Cosnier. An enzymatic biofuel cell based on electrically wired polyphenol oxidase and glucose oxidase operating under physiological conditions. Electrochimica Acta, 2012, 85 (15), pp.278-282. 10.1016/j.electacta.2012.08.072 . hal00797027

\section{HAL Id: hal-00797027 \\ https: / hal.sorbonne-universite.fr/hal-00797027}

Submitted on 24 Apr 2015

HAL is a multi-disciplinary open access archive for the deposit and dissemination of scientific research documents, whether they are published or not. The documents may come from teaching and research institutions in France or abroad, or from public or private research centers.
L'archive ouverte pluridisciplinaire HAL, est destinée au dépôt et à la diffusion de documents scientifiques de niveau recherche, publiés ou non, émanant des établissements d'enseignement et de recherche français ou étrangers, des laboratoires publics ou privés. 


\title{
An enzymatic biofuel cell based on electrically wired polyphenol oxidase and glucose oxidase operating under physiological conditions
}

\author{
Fabien Giroud ${ }^{\mathrm{a}}$, Chantal Gondran ${ }^{\mathrm{a}}$, Karine Gorgy ${ }^{\mathrm{a}}$, Vincent Vivier ${ }^{\mathrm{b}}$, Serge Cosnier*a \\ a. Département de Chimie Moléculaire, Université Joseph Fourier, UMR-5250, ICMG FR- \\ 2607, CNRS, Grenoble, France, \\ E-mail: serge.cosnier@ujf-grenoble.fr
}

b. LISE, UPR 15 du CNRS, Université Pierre et Marie CURIE, 4 Place Jussieu, 75252 Paris, France

\begin{abstract}
This paper reports the development and optimisation of a glucose/ $\mathrm{O}_{2}$ biofuel cell. At the anode, the glucose oxidation was performed by glucose oxidase (GOx) co-immobilised with a phenanthrenequinone mediator. At the cathode, the catalysis of $\mathrm{O}_{2}$ using tetrathiafulvalene and polyphenol oxidase (PPO) has been demonstrated for the first time. The open circuit voltage (OCV) of the optimised biofuel cell reached $0.32 \mathrm{~V}$, and the maximum power density achieved was $40.8 \mu \mathrm{W} \mathrm{cm} \mathrm{cm}^{-2}$ at $0.2 \mathrm{~V}$. This original new GBFC showed quasi-stability in both OCV and power density for more than 25 days.
\end{abstract}

Keywords: biofuel cell, glucose oxidase, polyphenol oxidase, tetrathiafulvalene, enzyme wiring 


\section{Introduction}

Throughout the last decade, the development of biofuel cells (BFC) that convert chemical energy into electrochemical energy via biochemical reactions has attracted great research attention [1-6]. The production of electricity is obtained via the oxidation of a fuel at the anode and the reduction of an oxidant at the cathode. For the glucose $/ \mathrm{O}_{2}$ biofuel cell, the oxidisable substrate is glucose and the oxidant is dioxygen. Enzymes are well-adapted to play the role of biocatalysts in biofuel cells. Due to the deep localisation of the redox active site of enzymes, the electron transfer from enzymes to electrodes can be achieved by direct electron transfer communication (DET) by using very specific materials [7-11] such as carbon nanotubes [9]. Another approach to insure the electron transfer is the introduction of artificial redox mediator molecules [12] such as osmium complexes [13, 14] and 2,2'-azino-bis(3ethylbenzothiazoline)-6-sulfonic acid [15, 16].

Glucose- $\mathrm{O}_{2}$ biofuel cells are interesting devices because of their in vivo availability, allowing their implantation in living organisms [17]. Since the first example reported about glucose- $\mathrm{O}_{2}$ biofuel implanted in the abdomen of a rat [17], different strategies regarding the method of implantation have been reported [18-21]. New implantable systems have been tested in cockroaches [20] and molluscs, in snails [18] and clams [19]. Nevertheless, for implantation, the activity of bioelectrodes must be stable in physiological fluids. The vast majority of BFC is based on the combination of glucose oxidase and laccase or bilirubin oxidase (BOD) for oxygen reduction. Although $\mathrm{GOx}$ is well-adapted for working at physiological $\mathrm{pH}$, the use of laccase or BOD is compromised in physiological fluids. Laccase operates mainly in acidic conditions and is inhibited in the presence of chloride while BOD is inhibited by urate [22]. An alternative consists of using polyphenol oxidase (PPO) to reduce oxygen, as we firstly reported for a PPO-based BFC implanted in rats. However, PPO was electrically wired by a water soluble redox mediator (quinhydrone) requiring the use of a dialysis bag to prevent in vivo quinhydrone release. The use of water-insoluble compounds should enhance the 
electrical connection with the enzyme and pave the way for a wider range of redox mediators

for the enzyme wiring. In this context, we report here the original screening of various poorly soluble redox mediators for PPO and for GOx via the use of a carbon cavity microelectrode (CME). It is a rapid and simple way to determine if a mediator is suitable for enzymatic electrocatalysis. It consists of using CME, filling the cavity with both the mediator and the associated enzyme and looking at the catalytic effect by electrochemical methods in presence of substrate.

The optimum mediated enzyme systems were then employed for the fabrication of a BFC by mechanical compression with graphite particles. We further investigated the optimisation of the BFC performance under physiological conditions.

\section{Experimental section}

\subsection{Material and reagents}

GOx type VII (Aspergillus niger, $\geq 168,800 \mathrm{U} \mathrm{g}^{-1}$ solid), catalase (from Bovine Liver, $1610 \mathrm{U}$ $\mathrm{mg}^{-1}$ ), PPO (from mushroom $3933 \mathrm{U} \mathrm{mg}^{-1}$ ), syringaldazine, ferrocene, 9,10phenanthrenequinone, 1,4-naphtoquinone, duroquinone and graphite flakes (GF) were purchased from Sigma-Aldrich. Tetrathiafluvalene (TTF) was purchased from Alfa Aesar, HEPES from Euromedex and $\mathrm{NaCl}$ from Carlo Erba. All chemicals were used as received. Distilled water $\left(18.5 \mathrm{M} \Omega \mathrm{cm}^{-1}\right)$ was used for all aqueous solutions.

\subsection{Electrode fabrication}

The carbon cavity microelectrode consists of a cylindrical cavity (about $45 \mu \mathrm{m}$ in diameter and $25 \mu \mathrm{m}$ in depth) which was filled with different mixtures of enzyme and redox mediator powders (1:1 weight ratio), using the electrode as a pestle [23]. Composite graphite discs containing enzyme and redox mediator were designed by mechanical compression with 
graphite particles [17]. Electrical contact was made through a platinum wire stuck by carbon paste glue.

\subsection{Electrochemical measurements}

All measurements were performed using an Autolab PGSTAT 30. A platinum wire and a SCE were used as counter and reference electrodes, respectively. Electrochemical measurements were performed at $25^{\circ} \mathrm{C}$ in HEPES buffer $\left(0.025 \mathrm{~mol} \mathrm{~L}^{-1}, \mathrm{pH}\right.$ 7.2) containing $\mathrm{NaCl}$ $\left(0.15 \mathrm{~mol} \mathrm{~L}^{-1}\right)$ and glucose $\left(5.510^{-3} \mathrm{~mol} \mathrm{~L}^{-1}\right)$. Solutions of D-glucose were prepared $24 \mathrm{~h}$ before experiments. The performance of the BFCs was examined by immersing the two bioelectrodes in a one-compartment cell. The BFC power $\left(P_{\text {cell }}\right)$ was measured using linear sweep voltammetry at $1 \mathrm{mVs}^{-1}$.

\section{Results and discussion}

\subsection{Electrocatalytic evidence of $\mathrm{O}_{2}$ reduction at TTF/PPO-based electrodes}

With the aim of suppressing the release of redox mediators and hence the use of an additional membrane at the biocathode surface, the electrical wiring of PPO, which has a formal potential of $0.30 \mathrm{~V} / \mathrm{SCE}$ [24], by poorly soluble redox mediators as ferrocene, syringaldazine, and tetrathiafulvalene (TTF) was examined. Firstly, the electrochemical behavior of these three mediators was evaluated by cyclic voltammetry with CME filled with redox mediator (Fig. 1A) by scanning the positive region first. As shown on Figure 1, the $\mathrm{E}_{1 / 2}$ values of these mediators are $0.203 \mathrm{~V} / \mathrm{SCE}(\Delta \mathrm{Ep}=0.153 \mathrm{~V}), 0.208 \mathrm{~V} / \mathrm{SCE}(\Delta \mathrm{Ep}=0.065 \mathrm{~V})$, and $0.165 \mathrm{~V} / \mathrm{SCE}(\Delta \mathrm{Ep}=0.273 \mathrm{~V})$ for ferrocene, syringaldazine, and TTF, respectively. The $\mathrm{E}_{1 / 2}$ value of syringaldazine is close to the potential of syringaldazine immobilised onto a hydrophobic porous silicate-carbon heterogeneous structure [25]. These results show the possibility of using poorly soluble mediators to insure the connection of PPO to electrode the 
TTF giving the larger currents even if its half wave potential is slightly lower than that of the other two.

The efficiency of the PPO connection to syringaldine, ferrocene and TTF was then investigated with CME filled with enzyme-redox mediator mixtures. Cyclic voltammograms were recorded with these modified CMEs in the presence and the absence of oxygen. For instance, Fig. 1B displays the electrochemical behaviour of a CME filled with a TTF/PPO mixture (ratio 1:1). Under argon, a peak system composed of an anodic peak at $0.25 \mathrm{~V} / \mathrm{SCE}$ associated to a cathodic peak at $0.06 \mathrm{~V} / \mathrm{SCE}$ was attributed to the reversible oxidation of TTF to $\mathrm{TTF}^{+}$. In $\mathrm{O}_{2}$-saturated condition, the anodic peak relative to the TTF oxidation decreases while the cathodic peak increases. This catalytic phenomenon was ascribed to the formation of $\mathrm{TTF}^{+}$generated during the electro-enzymatic reduction of $\mathrm{O}_{2}$ highlighting thus the efficient electrical wiring of PPO. The comparison of the different electrochemical behaviours indicates that TTF was the best candidate for establishing a stable electrical communication between PPO and the electrode. The PPO/TTF system was therefore investigated for the fabrication of compressed graphite electrodes.

On the linear sweep voltammogram from $0.15 \mathrm{~V} / \mathrm{SCE}$ to $-0.25 \mathrm{~V} / \mathrm{SCE}$ for a compressed graphite-TTF-PPO electrode, a cathodic peak appears at $-0.12 \mathrm{~V} / \mathrm{SCE}$ (Fig. 2A). It was attributed to the reduction of $\mathrm{TTF}^{+}$generated during the enzymatic reduction of $\mathrm{O}_{2}$. In addition, the same experiments performed with pressed graphite electrodes containing PPO or TTF show no reduction peak in this potential range, thus corroborating the efficient PPO wiring by TTF inside the graphite disc.

Finally, the operational stability of the bioelectrode was investigated by keeping the biocathode immersed in physiological conditions and determining its performance daily, via the bioelectrode polarisation. It appears that the open circuit potential (OCP) is stable for 28 days $(141 \pm 3 \mathrm{mV} / \mathrm{SCE})$ while the $\mathrm{I}_{\lim }$ value (recorded at $-0.1 \mathrm{~V} / \mathrm{SCE}$ ) remains stable for 22 days and then decreases to $57 \%$ of its initial value after 28 days (Fig. 2B). 


\subsection{Electrocatalytic glucose oxidation at PQ/GOx-Catalase-based electrodes}

As direct transfer between GOx and an underlying electrode is difficult or not possible $[26,27]$, in a similar way, the GOx wiring by 9,10-phenanthrenequinone, 1,4-naphtoquinone, and duroquinone was examined by cyclic voltammetry with CME. As described before for cathodic mediators, the anodic mediators have been characterised by cyclic voltammetry (figure 3A) with CME filled with respectively 9,10-phenanthrenequinone (PQ) (curve a) 1,4naphtoquinone (curve b), and finally duroquinone (curve c) by cycling the negative potentials first. The $\mathrm{E}_{1 / 2}$ measured are respectively $-0.208 \mathrm{~V} / \mathrm{SCE}(\Delta \mathrm{Ep}=0.164 \mathrm{~V}),-0.22 \mathrm{~V} / \mathrm{SCE}(\Delta \mathrm{Ep}=$ $0.160 \mathrm{~V})$, and $-0.045 \mathrm{~V} / \mathrm{SCE}(\Delta \mathrm{Ep}=1.150 \mathrm{~V})$. Currents for the three mediators are all of the same order of magnitude, PQ being the mediator with the lowest $\mathrm{E}_{1 / 2}$. To evaluate the electrocatalytic effect of GOx, Fig. 3B shows for example the cyclic voltammograms recorded at a CME filled with $\mathrm{PQ} / \mathrm{GOx}$ mixture in absence and presence of glucose. Without substrate, an ill-defined cathodic peak appears at $-0.290 \mathrm{~V} / \mathrm{SCE}$ attributed to the reduction of $\mathrm{PQ}$, combined with an anodic peak at $-0.164 \mathrm{~V} / \mathrm{SCE}$. In the presence of glucose $\left(0.03 \mathrm{~mol} \mathrm{\textrm {L } ^ { - }}\right.$ ${ }^{1}$ ), the efficient wiring of GOx by PQ is illustrated by the simultaneous decrease of the cathodic charge and the increase of the anodic one. The following resulting mechanism is suggested :

Glucose + GOx $($ FAD $) \rightarrow$ gluconolactone + GOx $\left(\mathrm{FADH}_{2}\right)$

$\mathrm{PQ}+\mathrm{GOx}\left(\mathrm{FADH}_{2}\right) \rightarrow \mathrm{PQH}_{2}+\mathrm{GOx}(\mathrm{FAD})$

In the presence of glucose $\left(5.5 \times 10^{-3} \mathrm{~mol} \mathrm{~L}^{-1}\right)$, the polarisation curve for a graphite-PQ-GOx disc shows an OCP of $-0.175 \mathrm{~V} / \mathrm{SCE}$ (figure 4A) with a maximum anodic current intensity $(202 \mu \mathrm{A})$ at $0.076 \mathrm{~V} / \mathrm{SCE}$. In contrast, OCP values for graphite, graphite-GOx and graphitePQ were in the positive region, confirming the GOx wiring by PQ (Fig. 4A). 
The operational stability of the bioanode was also examined by soaking the bioanode continuously in a $5.5 \times 10^{-3} \mathrm{~mol} \mathrm{~L}^{-1}$ glucose solution. After an initial stabilisation period, OCP and $\mathrm{I}_{\mathrm{lim}}$ (recorded at $+0.1 \mathrm{~V} / \mathrm{SCE}$ ) values remain remarkably stable for 120 days (Fig. 4B).

\subsection{Optimisation of biocathode and bioanode}

In order to design the optimum BFC configuration, the influence of graphite/mediator ratio or enzyme/mediator ratio on the bioelectrode performance was examined. Table 1 summarises the OCP and $\mathrm{I}_{\lim }$ values recorded for the different bioelectrode configurations. It appears that $\mathrm{O}_{2}$ electro-reduction and glucose electro-oxidation currents were dependent on both ratios. It should be noted that the optimum value for $\mathrm{I}_{\lim }$ was considered to be more important than the OCP value to determine the optimum configuration. For the bioanode, the importance of the choice of the ratio between carbon graphite and the mediator is also important. The influence of the proportion of PQ was measured for carbon /PQ ratios ranging from 95/5 to 33/66 (for a total mass of $100 \mathrm{mg}$ ) and for $3.3 \mathrm{mg}$ of GOx (Table 1). Comparing the anodic polarisation curves of electrodes with several different mass ratios, it appears that the best performance is obtained for a ratio of $75 / 25$ with a current of $44.6 \mu \mathrm{A}$ at a potential of $66 \mathrm{mV}$. Once this parameter is set, the increase of the proportion of enzymes indicates that the value of current measured at the catalytic oxidation potential of PQ is proportional to the amount of enzyme immobilised on the electrode. So, $25 \mathrm{mg}$ PQ and $13.2 \mathrm{mg}$ GOx for $75 \mathrm{mg}$ graphite constitute the optimum composition that corresponds to a molecular mediator/enzyme ratio of 600 taking into account the price of enzymes for the production of the electrodes.

As for the cathode, the influence of the proportion of TTF was measured for carbon/TTF ratios ranging from $25 / 75$ to $98 / 2$ (for a total mass of $100 \mathrm{mg}$ ) and $5 \mathrm{mg}$ of PPO (Table 1). The catalytic effect of PPO on the TTF was measured for three different concentrations of the enzyme. The increase in this enzyme/mediator ratio induces a small increase $(10 \%$ for the 
current) which is negligible. Thus, the optimum biocathode configuration was $5 \mathrm{mg}$ TTF and $5 \mathrm{mg}$ PPO for $95 \mathrm{mg}$ graphite that corresponds to a molecular mediator/enzyme ratio of 1500 .

\subsection{Performance of the BFC under physiological conditions}

Fig. 5A shows the dependence of the current and the power as a function of the cell voltage in aqueous solution ( $\mathrm{pH} 7.2$ ) containing $5.5 \times 10^{-3} \mathrm{~mol} \mathrm{~L}^{-1}$ of glucose. OCP reached $0.32 \mathrm{~V}$ and the maximum power density, calculated from the polarization curve, was $40.8 \mu \mathrm{Wcm}^{-2}$ at $0.2 \mathrm{~V}$ of the cell voltage. It should be noted the good correlation between the BFC performances determined by cyclic voltammetry at $1 \mathrm{mVs}^{-1}$ and calculated from the chronopotentiometric curves (Fig. 3A) as previously reported [28]. The relatively low power output is due to the weak operating voltage of the cell, which is mainly due to the biocathode potential induced by TTF. Although the TTF potential was less positive than those used in other biocathodes $[29,30]$, its hydrophobic character reinforces the stability of the biocathode. As expected, the BFC stability (25 days) is in good agreement with the stability of each bioelectrode measured separately.

Compared to the previously fabricated biofuel cells [17], by changing the mediators at both electrodes, performances of the biofuel cell have been improved; the open circuit potential shifted from $0.246 \mathrm{~V}$ to $0.320 \mathrm{~V}$ in association with an increase of the power output by a factor of 13.5 .

The operational stability of the BFC was investigated by recording the cell voltage as a function of time for constant current discharges from 10 to $50 \mu \mathrm{A}$ (Fig. 5B). As expected, the cell voltage decreases with an increase of the discharge current. For a current of $50 \mu \mathrm{A}$, the cell voltage drops to $45 \%$ of its initial value over 2 minutes whereas for a $10 \mu \mathrm{A}$ discharge, only a slow decrease of the voltage $(9 \%)$ is observed, illustrating the potentialities of this BFC. 


\section{Conclusion}

Herein, we have reported the original use of cavity microelectrodes for the choice of the redox mediators able to connect enzymes for BFC. The combination of PPO and TTF led to a biocompatible biocathode for oxygen reduction. Its association with a bioanode based on GOx and 9,10-phenanthrenequinone provided a BFC able to operate under physiological conditions and hence be used for implantation in living tissues. It is expected that this easy screening tool and fabrication procedure for enzyme electrodes will facilitate the development of a new generation of biofuel cells.

\section{Acknowledgments}

The authors thank the platform "functionalization of surfaces and transduction" of the scientific structure "Nanobio campus" for providing facilities, and Arielle Le Pellec for technical assistance and fruitful discussions. They also thank the Interdisciplinary Program Energy of CNRS « PR10-1-1 (Biopile animale) » for partial financial support.

\section{References}

[1] I. Willner, Y. Yan, B. Willner, R. Tel-Vered, Fuel Cells, 9 (2009) 7.

[2] M.H. Osman, A.A. Shah, F.C. Walsh, Biosens. Bioelectron., 26 (2011) 3087.

[3] R. A. Rincón, C. Lau, H. R. Luckarift, K. E. Garcia, E. Adkins, G. R. Johnson, P. Atanassov, Biosens. Bioelectron., 27 (2011) 132.

[4] F. Gao, L. Viry, M. Maugey, P. Poulin, N. Mano, Nature Commun., 1 (2010) 110.1038/ncomms1000.

[5] S.-N. Ding, M. Holzinger, C. Mousty, S. Cosnier, J. Power Sources, 195 (2010) 4714.

[6] S. Cosnier, D. Shan, S.-N. Ding, Electrochem.Commun., 12 (2010) 266.

[7] A.Guisepii-Elie, C.H.Lei, R.H. Baughman, Nanotechnology, 13 (2002) 559.

[8] D. Ivnitski, B. Branch, P. Atanassov, C. Apblett, Electrochem.Commun., 8 (2006) 1204.

[9] A. Zebda, C. Gondran, A. Le Goff, M. Holzinger, P. Cinquin, S. Cosnier, Nature Commun., 2 (2011) 370. 
[10] A. Vaze, N. Hussain, C. Tang, D. Leech, J. Rusling, J. Electrochem. Commun., 11 (2009) 2004.

[11] M. Holzinger, A. Le Goff, S. Cosnier, Electrochim. Acta, in press (doi: 10.1016/j.electacta.2011.12.135).

[12] T. Nöll, G. Nöll, Chem.Soc. Rev.,40 (2011) 3564.

[13] V. Flexer, N. Mano, Anal. Chem., 82 (2010) 1444.

[14] M. Nadeem Zafar, N. Beden, D. Leech, C. Sygmund, R. Ludwig, L. Gorton, Anal. Bioanal. Chem., 402 (2012) 2069.

[15]A. Habrioux, K. Servat, S. Tingry, K. B. Kokoh, Electrochem.Commun., 11 (2009) 111.

[16] P.Jenkins, S. Tuurala, A. Vaari, M. Valkiainen, M. Smolander , D. Leech, Bioelectrochemistry, (doi :10.1016/j.bbr.2011.03.031).

[17] P. Cinquin, C. Gondran, F. Giroud, S. Mazabrard, A. Pellissier, F. Boucher, J.P. Alcaraz, K. Gorgy, F. Lenouvel, S. Mathe, P. Porcu, S. Cosnier, Plos One, 5 (2010) No.e10476.

[18] L. Halámková, J. Halámek, V. Bocharova, A. Szczupak, L. Alfonta, E. Katz, J. Am. Chem. Soc. , 134 (2012) 5040.

[19] A. Szczupak, J. Halamek, L. Halámková, V. Bocharova, L.Alfonta, E. Katz, Energy

Environ. Sci. 2012, (doi : 10.1039/c2ee21626d).

[20] M. Rasmussen, R. E. Ritzmann, I. Lee, A. J. Pollack, D. Scherson, J. Am. Chem. Soc., 134 (2012) 1458.

[21] U. Schröder, Angew. Chem. Ind. Ed, (doi :10.1002/anie.201203259)

[22] S.C. Barton, J. Gallaway, P. Atanassov, Chem. Rev., 104 (2004) 4867.

[23] S. Cosnier, R.E. Ionescu, M. Keddam, V. Vivier, Electroanalysis, 20 (2008) p750.

[24] B. Reuillard, A. Le Goff, C. Agnès, A. Zebda, M. Holzinger, S. Cosnier, Electrochem. Comm. 20 (2012) 19.

[25] W. Nogala, E. Rozniecka, J. Rogalski, M. Opallo, J. Electranal. Chem., 608 (2007) 31.

[26] J. Wang, Chemical reviews, 108 (2008) 814.

[27] E. Hao Yu, K. Scott, Energies, 3 (2010) 23.

[28] H. Sakai, T. Nakagawa, Y. Tokita, T. Hatazawa, T. Ikeda, S. Tsujimura, K. Kano, Energy \& Environmental Science, 2 (2009) 133.

[29] A. Zebda, L. Renaud, M. Cretin, C. Innocent, R. Ferrigno, S. Tingry, Sensors and Actuators B: Chemical, 149 (2010) 44.

[30] P.A. Jenkins, S. Boland, P. Kavanagh, D. Leech, Bioelectrochemistry, 76 (2009) 162. 
Table 1: Electrochemical characteristics of bioelectrodes immersed in aqueous solutions mimicking the physiological fluids and exhibiting various graphite/mediator/enzyme loadings. Mediators were 9,10-phenanthenequinone (PQ) at the anode and tetrathiafulvalene (TTF) at the cathode. Enzymes were GOx and catalase at the anode and PPO at the cathode.

Fig. 1: A- Cyclic voltammograms recorded at $100 \mathrm{mV} \mathrm{s}^{-1}$ at a carbon CME filled with (a) ferrocene, (b) syringaldazine, (c) tetrathiafulvalene immersed in a buffered aqueous solution. B- Cyclic voltammograms recorded at $100 \mathrm{mV} \mathrm{s}^{-1}$ at a carbon CME filled with a TTF/PPO 1:1 mixture and immersed in a buffered aqueous solution under an argon (line) or $\mathrm{O}_{2}$ (dots) atmosphere.

Fig.2: A- Polarization curves of compressed graphite electrodes: graphite (line), graphite/TTF (dashes), graphite/PPO (dots) and graphite /TTF/PPO (red dots) at $1 \mathrm{mV} \mathrm{s}^{-1}$. B- Stability of OCP (circles) and $\mathrm{I}_{\lim }$ at $-0.1 \mathrm{~V} / \mathrm{SCE}$ (squares) values obtained for a biocathode. There is an uncertainty of $\pm 3 \mathrm{mV}$ for $\mathrm{E}$ and $\pm 2 \mu \mathrm{A}$ for $\mathrm{I} .0 .15 \mathrm{~mol} \mathrm{~L}^{-1} \mathrm{NaCl}, 0.025 \mathrm{~mol} \mathrm{~L}^{-1}$ HEPES (pH $\left.7.2,20^{\circ} \mathrm{C}\right)$.

Fig. 3: A- Cyclic voltammograms recorded at $100 \mathrm{mV} \mathrm{s}^{-1}$ at a carbon CME filled with (a) 9,10-phenanthenequinone (b) 1,4 naphtoquinone (c) duroquinone immersed in a buffered aqueous solution. B- Cyclic voltammograms recorded at $100 \mathrm{mV} \mathrm{s}^{-1}$ at a carbon CME filled with a PQ/GOx 1:1 mixture and immersed in a buffered aqueous solution in presence (dots) or absence (line) of glucose $\left(0.03 \mathrm{~mol} \mathrm{~L}^{-1}\right)$.

Fig.4: A- Polarization curves of compressed graphite electrodes: graphite (line), graphite/PQ (dashes), graphite/GOx (dots) and graphite/PQ/GOx (blue dots) at $1 \mathrm{mV} \mathrm{s}^{-1}$. B- Stability of OCP (circles) and $\mathrm{I}_{\mathrm{lim}}$ at $+0.1 \mathrm{~V} / \mathrm{SCE}$ (squares) values obtained for a bioanode. There is an uncertainty of $\pm 3 \mathrm{mV}$ for $\mathrm{E}$ and $\pm 2 \mu \mathrm{A}$ for $\mathrm{I}$. Buffered aqueous solution $\left(\mathrm{pH} 7.2,20^{\circ} \mathrm{C}\right)$ containing $0.15 \mathrm{~mol} \mathrm{~L}^{-1} \mathrm{NaCl}, 0.025 \mathrm{~mol} \mathrm{~L}^{-1}$ HEPES and glucose $\left(5.510^{-3} \mathrm{~mol} \mathrm{~L}^{-1}\right)$ for polarization curves and stability experiments.

Fig. 5: A- Polarization curve obtained at $1 \mathrm{mVs}^{-1}$ for a BFC (line) based on graphite /TTF/PPO and graphite/PQ/GOx discs and dependence of the power output as a function of the current. Dotted values (triangle and cross) correspond to chronopotentiometric determination. Potential values (cross) measured after 120 seconds of constant current discharges in the range 10-50 $\mathrm{A}$. B- Evolution of the BFC voltage as a function of time for 
constant current discharges from 10 to $50 \mu \mathrm{A}$. Experimental conditions: aqueous solution ( $\mathrm{pH}$ $\left.7.2,20^{\circ} \mathrm{C}\right)$ containing $\mathrm{NaCl}\left(0.15 \mathrm{~mol} \mathrm{~L}^{-1}\right)$, HEPES $\left(0.025 \mathrm{~mol} \mathrm{~L}^{-1}\right)$ and glucose $\left(5.5 \times 10^{-3}\right.$ $\left.\mathrm{mol} \mathrm{L}^{-1}\right)$. 
Table 1

\begin{tabular}{|c|c|c|c|c|}
\hline Electrode & Mediator (mg) & Enzymes (mg) & $\begin{array}{c}\text { OCP (V) } \\
\text { Value } \pm \\
0.003 \mathrm{~V}\end{array}$ & $\mathbf{I}_{\lim }(\mu \mathrm{A})$ \\
\hline \multirow{9}{*}{$\begin{array}{c}\text { bioanode } \\
\text { (Mediator: PQ } \\
\text { Enzymes: GOx - } \\
\text { Catalase) }\end{array}$} & 66 & $3.3-1.6$ & -0.059 & $5.0 \pm 0.1$ \\
\hline & 50 & $3.3-1.6$ & -0.067 & $12.7 \pm 0.2$ \\
\hline & 25 & $3.3-1.6$ & -0.112 & $44.6 \pm 0.3$ \\
\hline & 10 & $3.3-1.6$ & -0.1390 & $34.1 \pm 0.2$ \\
\hline & 5 & $3.3-1.6$ & -0.080 & $22.3 \pm 0.2$ \\
\hline & 0 & $3.3-1.6$ & 0.104 & - \\
\hline & 25 & $6.6-3.2$ & -0.175 & $95.9 \pm 0.8$ \\
\hline & 25 & $13.2-6.4$ & -0.168 & $191 \pm 2$ \\
\hline & 25 & $19.8-9.6$ & -0.163 & $215 \pm 2$ \\
\hline \multirow{9}{*}{$\begin{array}{c}\text { biocathode } \\
\text { (Mediator: TTF } \\
\text { Enzyme: PPO) }\end{array}$} & 75 & 5 & 0.117 & $-35.9 \pm 0.2$ \\
\hline & 50 & 5 & 0.111 & $-62.7 \pm 0.6$ \\
\hline & 25 & 5 & 0.111 & $-81.2 \pm 0.7$ \\
\hline & 10 & 5 & 0.129 & $-118 \pm 1$ \\
\hline & 5 & 5 & 0.130 & $-151 \pm 2$ \\
\hline & 2 & 5 & 0.149 & $-118 \pm 1$ \\
\hline & 0 & 5 & 0.090 & $-4.0 \pm 0.1$ \\
\hline & 10 & 10 & 0.129 & $-130 \pm 2$ \\
\hline & 10 & 2.5 & 0.124 & $-109 \pm 2$ \\
\hline
\end{tabular}


Fig. 1
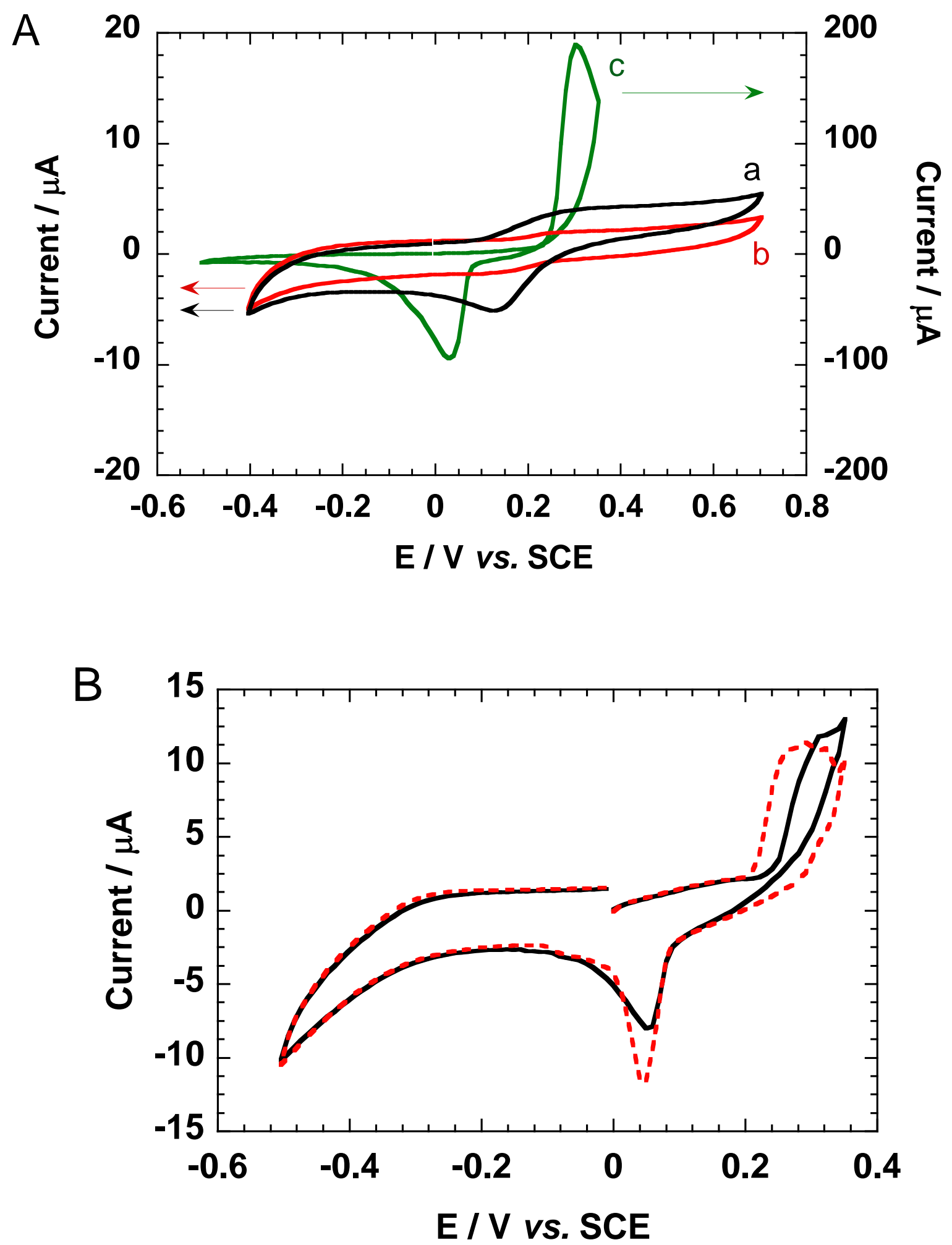
Fig. 2
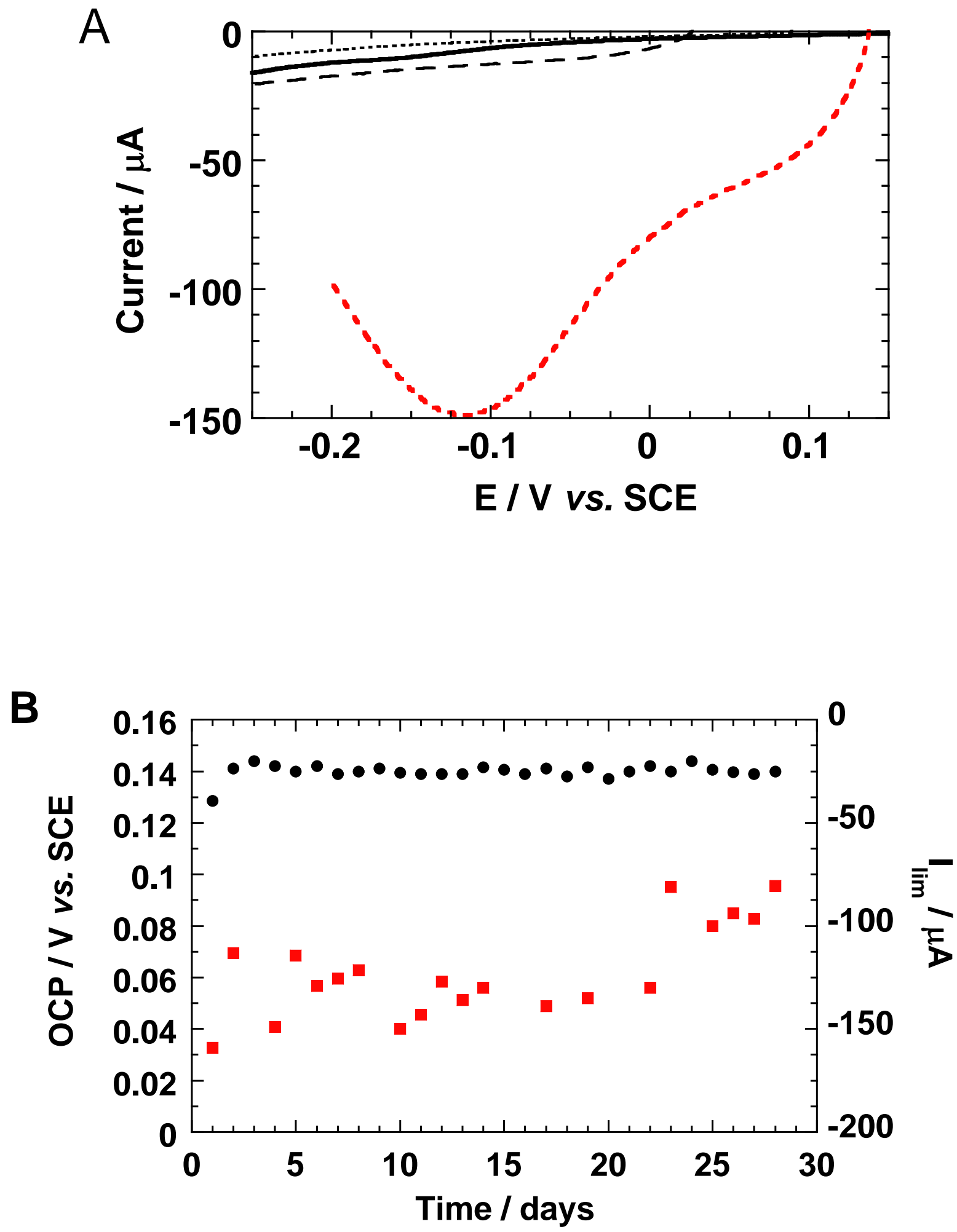
Fig.3

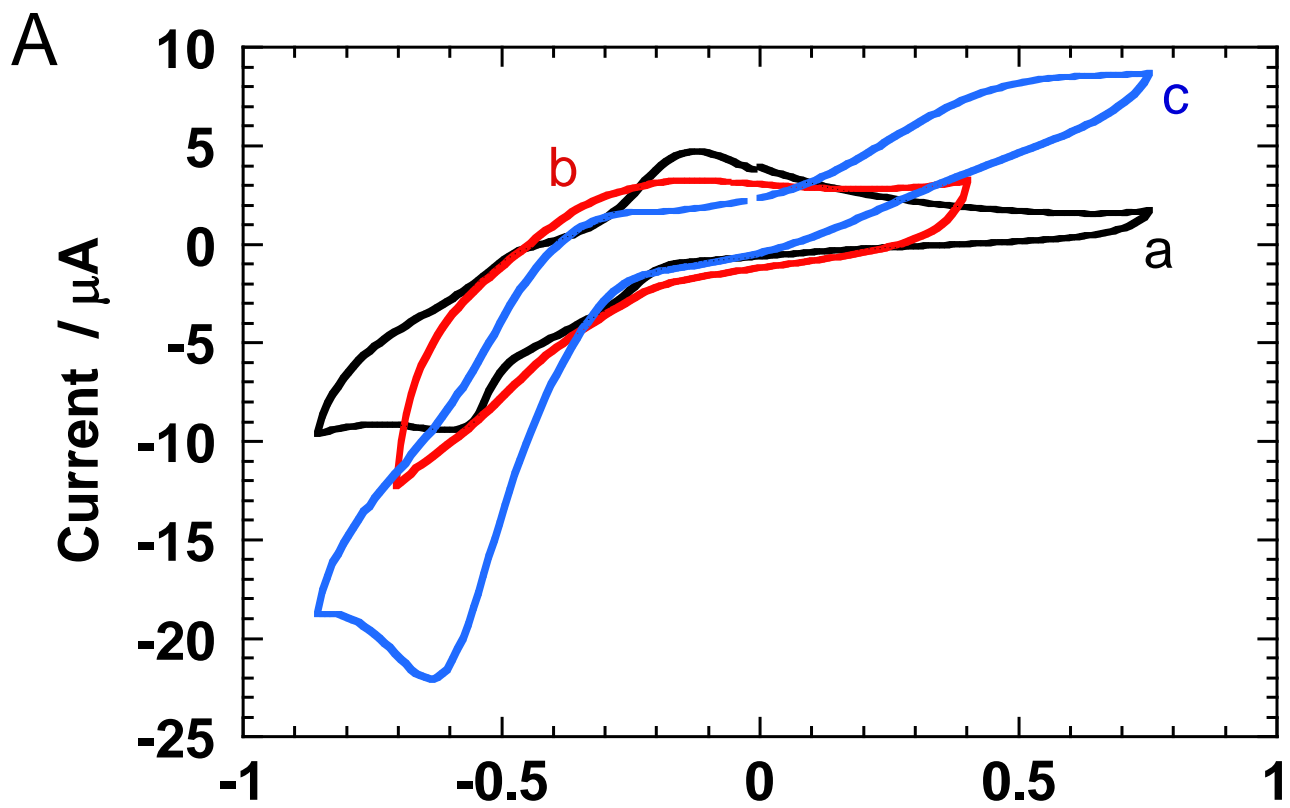

E I V vs. SCE

B

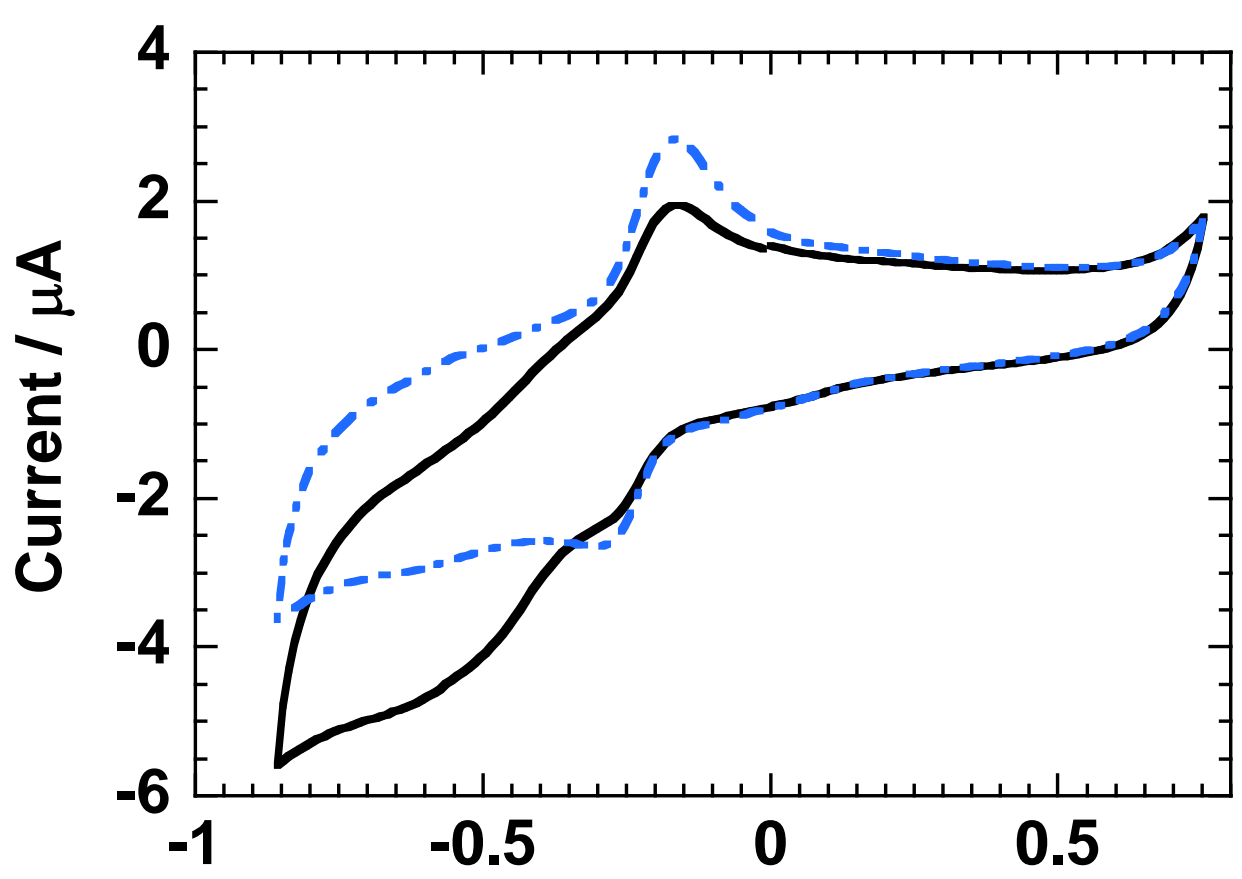

E I V vs. SCE 
Fig. 4
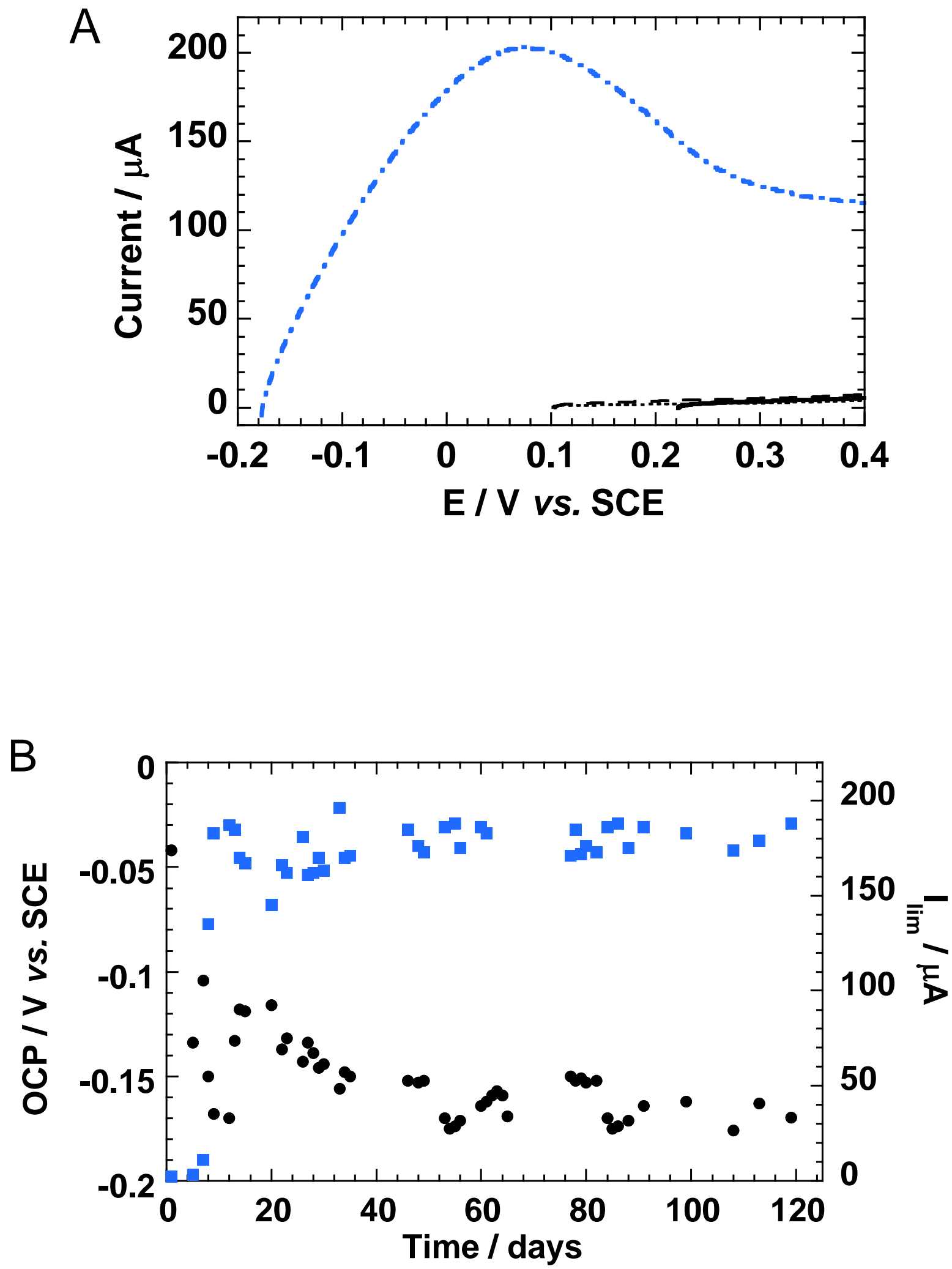
Fig. 5
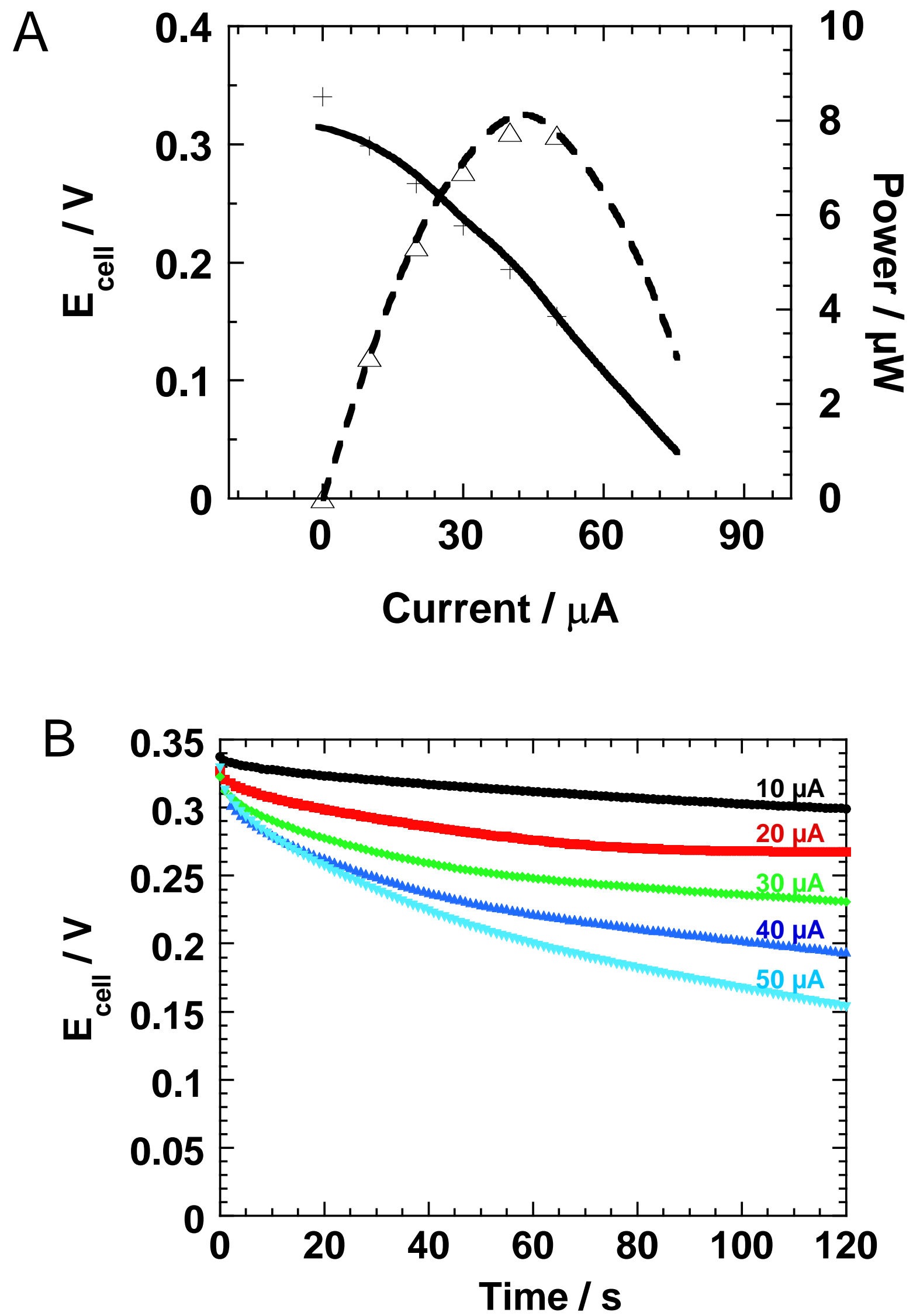